\title{
Childhood Cerebral Ependymoma
}

National Cancer Institute

\section{Source}

National Cancer Institute. Childhood Cerebral Ependymoma. NCI Thesaurus. Code C6268.

A cerebral ependymoma that occurs during childhood. 